\title{
Indonesian's Acceptance of Non-Cash Transaction Using Qris
}

\author{
Taufiq Andre Setiyono \\ Accounting \\ Bank BPD Jateng School of Economics and Business \\ Semarang, Indonesia \\ taufiq@stiebankbpdjateng.ac.id
}

\begin{abstract}
This research aims to determine the Indonesian's acceptance of non-cash transaction using QRIS. The data of this research were obtained from questionnaire given to 277 respondent, processed using descriptive statistic analysis. The result of this research indicate that more than $\mathbf{5 0}$ percent Indonesians don't know about QRIS. The result also show that 54,8 percent Indonesians prefer cash to non-cash transaction. It's due to Indonesians habit, lack of knowledge about digital finance, also high concern of transaction risk using e-wallets.
\end{abstract}

Keywords: non-cash transaction, e-wallet, QRIS

\section{INTRODUCTION}

NDRC defines fintech as a term that can be used to refer to innovations in financial or financial services, in this case financial innovation given a touch of modern technology. Fintech helps maximize the use of technology to sharpen, transform and accelerate various aspects of services. So payment methods, fund transfers, loans, fundraising, to asset management can be done quickly and briefly. One of the top fintech products that are widely used by Indonesians is an electronic wallet or e-wallet.

In August 2014, Bank Indonesia launched the National Non-Cash Movement (GNNT), in which one of the policies was the use of electronic money (e-money) for toll road rates, parking fees, cards for payments of various modes of transportation, and vending machines. As of May 2020, there are 51 e-money providers that have obtained permission from Bank Indonesia, most of which are registered e-wallet operators.(1)

Before the official regulation was issued, Bank Indonesia had implemented a standardized QR code implementation as a payment method. Most of the emoney providers have also developed $\mathrm{QR}$ payments. The goal is that if Bank Indonesia is ready with a QR code standard, the public will get used to using QR payments. On January 1, 2020, Bank Indonesia requires all noncash payment service providers to use the QRIS system (Quick Response Code Indonesian Standard).

According to the official website of Bank Indonesia, QRIS is a unification of various kinds of QR from various Payment System Service Providers (PJSP) using a QR code. QRIS was developed by the payment system industry with Bank Indonesia to make the transaction process using QR code easier, faster, and more secure.
All PJSPs who will use QR Code Payments are required to implement QRIS. By implementing QRIS, all payment applications from any Provider used by the public, both banks and non-banks, can be used in all stores, merchants, stalls, parking, tourist tickets, donations (merchants) bearing the QRIS logo, even though QRIS providers at merchants are different from application providers used by the community.

Non-cash payment transactions using QRIS offer various advantages over cash. For payment application users, transaction will be faster and up to date, users also don't have to bother carrying cash and don't need to think about whose QR is installed, because QRIS can be read on all e-wallet applications. In addition, e-wallet users who pay using QRIS also protected because the PJSP administering QRIS is definitely licensed and supervised by Bank Indonesia. (2)

In addition, merchants who use QRIS also get a number of conveniences and benefits, including the potential for increased sales because they can accept any QR-based payment, while also increasing branding. Merchants also only need to install a QRIS, so it's more practical and there is no need to provide change and avoid counterfeit money. By using QRIS, each transaction will be recorded automatically and can be seen at any time, thus enabling merchant to avoid fraudulent acts of accounting for cash transactions. Business money also will be separated from personal money. (2)

Beside the various benefits obtained from non-cash transactions using QRIS, there are several weakness and things that make people doubt about non-cash transactions. Among of them are lack of public confidence in security of the data they upload or the perception that other parties can access their accounts, the habit of transacting in cash, and the perception that digital transaction will leave traces. In addition, cash can be accepted anywhere, while digital money has not been accepted by some people, especially who have not been get digital financial services. (3)

Several studies on digital wallets are research by (4), (5), (6)and(7). Most of Indonesians initially used ewallets because of promotion, but over time people found it easier to use e-wallets so they no longer depend on promotions. However, previous research is limited to case studies of certain e-wallet applications. This study examines the level of public acceptance of non-cash transactions using QRIS, based on the advantages and 
disadvantages of the community as users. The shortcomings identified can be used as Bank Indonesia's evaluation for planning the next QRIS policy strategy.

\section{METHODS OF RESEARCH}

This research was conducted using qualitative research methods. This research was analyze the level of public acceptance of the payment methods using QRIS. This research uses primary data sources obtained through a questionnaire distributed via google form. There were 277 respondents. The analysis is carried out by comparing the data and interpreting it with existing theoretical support. The result of thisinterpretation are used to draw conclusions.

\section{RESULT AND DISCUSSIONS}

\section{Gender}

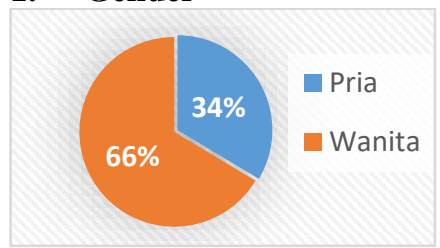

Fig. 1. Gender

Of the 277 respondents, 184 were female and 93 were male respondents. Respondent in this study were dominated by women, 66.4 percent.

\section{Age}

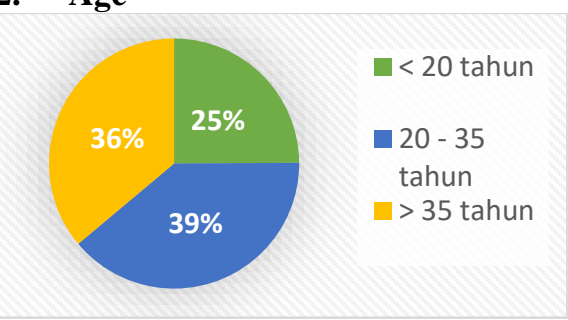

Fig. 2. Age

69 respondents were less than 20 years old, 108 respondents were about 20 to 35 years old, and 100 respondents were over than 35 years old. This research were dominated by about 20 to 35 years old respondent, 39 percent.

\section{Income}

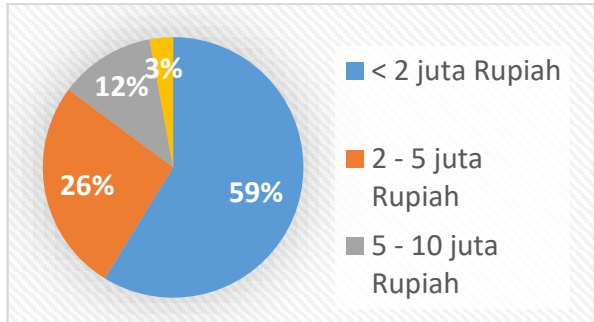

Fig. 3. Income
163 respondents earn less than 2 million Rupiah per month. 73 respondents earn between 2 to 5 million Rupiah per month. 33 respondents earn between 5 and 10 million Rupiah per month. 8 respondents earn more than 10 million Rupiah per month. This research were dominated by the group with a monthly income of less than 2 million Rupiah.

\section{Spending}

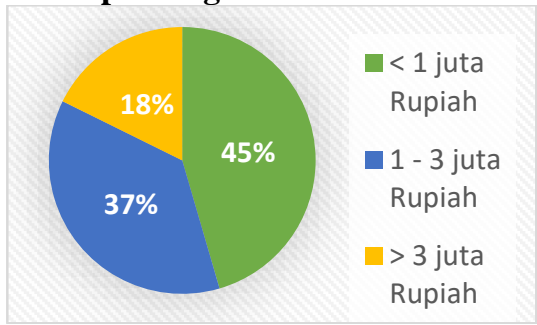

Fig. 4. Spending

126 respondents spent less than 1 million Rupiah per month. 102 respondents spent a month between 1 and 3 million Rupiah. 49 respondents spend more than 3 million Rupiah per month. This research were dominated by the group with a monthly expense of less than 1 million Rupiah.

\section{E-Wallet User}

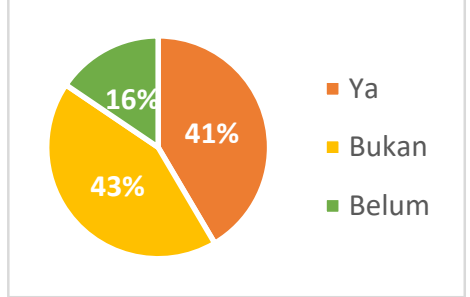

Fig. 5. E-wallet user

115 respondents are e-wallet users, 119 respondents are not e-wallet users and have no interested in using ewallets, and 43 respondents are not e-wallet users but interested to use e-wallets. This research were dominated by non e-wallet users.

\section{Most Used e-Wallet}

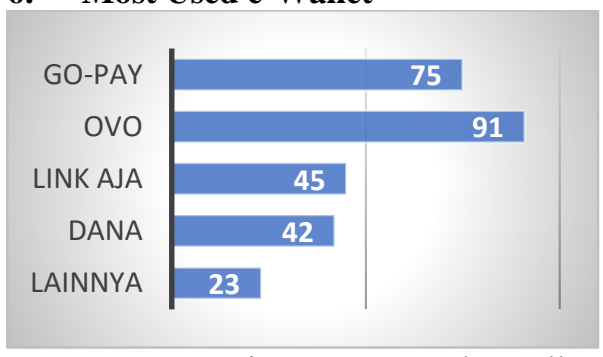

Fig. 6. Most used e-wallet

Of the 115 respondents using e-wallet, 75 respondents are Go-Pay users, 91 respondents are OVO users, 45 respondents are Link Aja users, 42 respondents are Dana users, and 23 respondents are e-wallet users other than mentioned, including Shopee-Pay, BRIZI, i-Saku, and Paytren. Most of the respondents have more than one e- 
wallet application. Respondents in this research were dominated by OVO users.

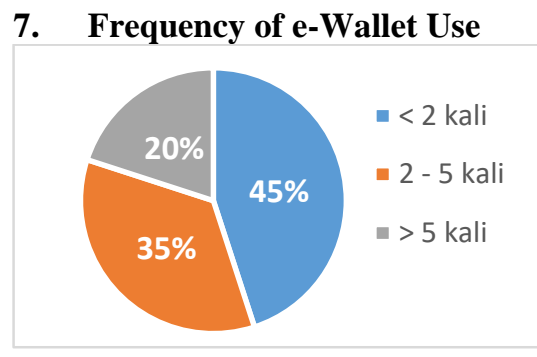

Fig. 7. Frequency of e-wallet use

Of the 115 e-wallet users, 45 percent of respondents use e-wallets less than 2 times a month, 35 percent of respondents use e-wallets about 2 to 5 times a month, and 20 percent of respondents use e-wallets about more than 5 times a month.

\section{Reasons for using e-Wallet}

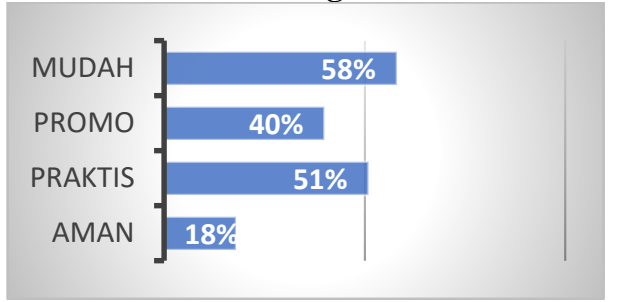

Fig. 8. Reasons for using e-wallet

Of the 115 e-wallet users, 58percentchoose to use ewallets because the transactions were easier, 51percent choose to use e-wallets because the transactions were more practical. 40percent choose to use e-wallets because of the promos given in the form of discounts or cashbacks, while 18percent using e-wallets for security reasons from theft. Respondents can have more than one reason for using e-wallets.

\section{QRIS Introduction}

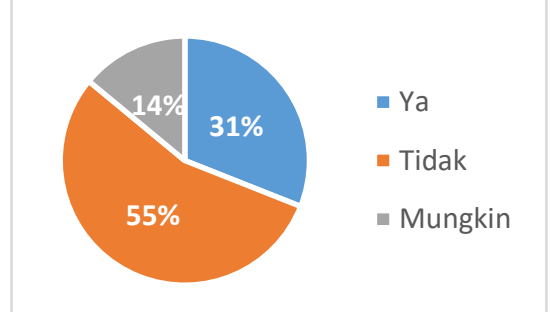

Fig. 9. QRIS introduction

Of the 277 respondents, 55percent didn't know and had never heard of QRIS. 31 percent know about QRIS, and 14 percent of respondents are doubtful. Respondents in this research were dominated by group of people who didn't know and had never heard of QRIS. These result indicate that most people still don't know about QRIS. In fact, there are still many e-wallet users also don't know about QRIS, because they use e-wallets for online shopping payments or transfers, but not used for payment via $\mathrm{QR}$ code scan.

\section{The Understanding of QRIS}

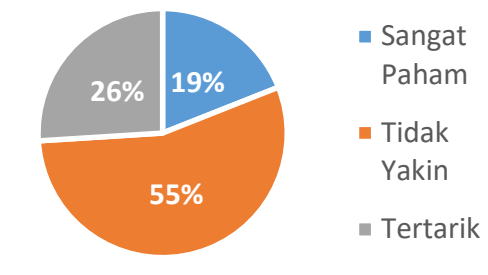

Fig. 10. The understanding of QRIS

Of the 277 respondents, 55percent don't understand about QRIS and worried about the security risk of transacting using QRIS. These result indicate that most people are still not sure whether to make or accept payments by scanning the QR code. Indonesian people are more familiar with transfer payment via e-wallet or m-banking.

\section{Usefulness Perception}

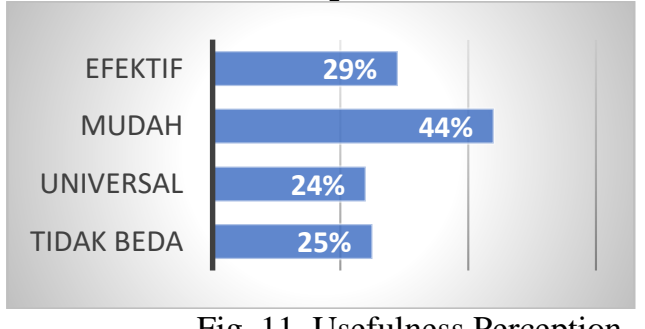

Fig. 11. Usefulness Perception

44 percent of respondent felt QRIS made it easier to make transactions. 29percent of respondent think that QRIS can increase the effectiveness in making transaction. 24percent of respondent feel that there is no worry that e-wallet they used is different from the merchant's, because QRIS make the QR be universal. 25percent didn't feel any difference before and after QRIS. The result indicate that most of the people who have used QRIS and plan to use QRIS see the advantages obtained in the form of ease of transactions.

\section{Safety Perception}

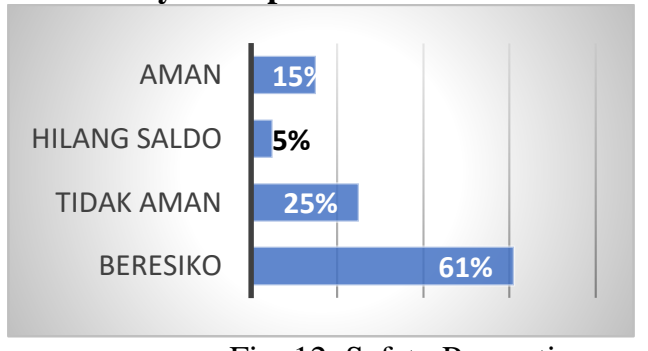

Fig. 12. Safety Perception

61 percent of the respondent feel that after QRIS the risk of using e-wallet is higher. 25percent feel that it's no longer safe to transact using e-wallet. 5percent felt that transact using e-wallet were still safe even after QRIS was established. These result indicate that there are still many people who don't know about QRIS, so they have a negative perception of the e-wallet's security. 


\section{Trust Perception}

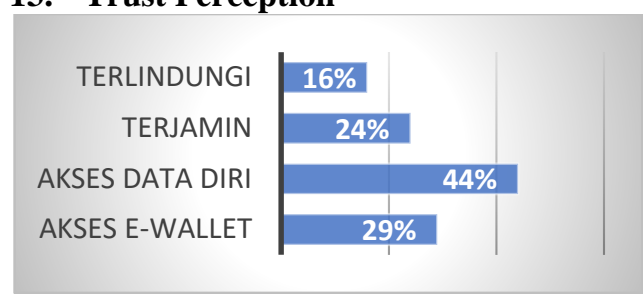

Fig. 13. Trust Perception

44 percent of respondents are worried that other parties can access their personal data, and 29 percent others are worried about their e-wallet data. 16percent of respondents have no doubt that application they used can protect their personal data, and 24percent others believe the e-wallet application they used has good transaction guarantees. These result indicate that the ease of transactions after QRIS is still accompanied by high concerns from users and potential users.

\section{Ease of Use Perception}

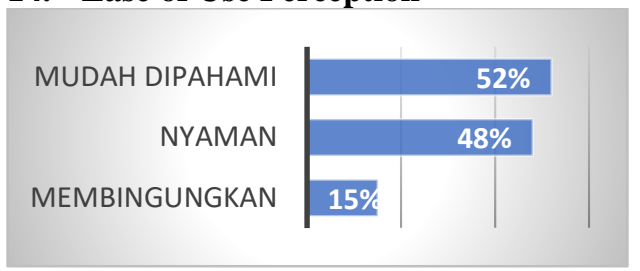

Fig. 14. Ease of use perception

$52 \%$ of respondent feel that transact using QRIS scans is easy to understand. $48 \%$ of respondents feel that transact using QRIS are very convenient because QR codes can be accepted by all e-wallet applications. $15 \%$ others felt that transact using QRIS were confusing and not easy to understand. These result indicate that most QRIS users are easy to adapt from using cash transaction to non-cash transactions through scanning QR code.

\section{Transaction Method}

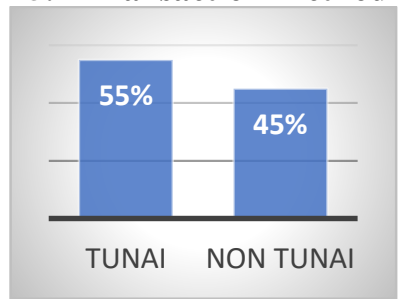

Fig. 15. Transaction method

Of the 277 respondents, 152 of them (55percent) preferred cash transactions. Meanwhile the remaining, 125 respondents (45percent) preferred non-cash transactions. These result indicate that most Indonesians still tend to choose to transact traditionally by cash.

\section{CONCLUSIONS}

There are still many Indonesian people who have never heard of or know about QRIS. More than 50percent of respondents in this study didn't know what QRIS was, even employees of a merchant who used QRIS didn't necessarily know the difference between QRIS and the previous QR code. 55percent of respondents in this study also prefer traditional transactions rather than non-cash transactions. These result indicate that the Indonesians acceptance of non-cash transactions using QRIS is still not optimal, so that the government and Bank Indonesia still need to socialize the advantages of non-cash transactions using QRIS.

\section{REFERENCES}

1. Indonesia, Bank. Bank Indonesia. Bank Indonesia Mencanangkan Gerakan Nasional Non Tunai. [Online] 2014. [Dikutip: 24 Oktober 2020.] https://www.bi.go.id/id/ruang-media/siaranpers/pages/sp_165814.aspx

2. —. Bank Indonesia. QRIS. [Online] 2019. [Dikutip: 19 Oktober 2020.] https://www.bi.go.id/QRIS/Contents/Default.aspx.

3. Kothari, Satyen. The Economic Times. 5 Reasons Why Consumers Still Don't Use Digital Payments. [Online] 2018. [Dikutip: 23 Oktober 2020.] https://m.economictimes.com/wealth/spend/5reasons-why-consumers-still-dont-use-digitalpayments/amp_articleshow/64699938.cms.

4. Persepsi Digital Wallet di Indonesia, Studi Kasus pada Go-Pay. Chandra, Yakob U. 1, s.1. : Infotech, 2018, Vol. 4.

5. Pengaruh e-Wallet terhadap Perilaku Konsumtif Generasi Milenial di Wilayah Jabodetabek (Studi Kasus pada Layanan OVO). Rofiqoh, DAA. s.1. : ResearchGate, 2019.

6. Covid-19 and e-Wallet Usage Intention: A Multigroup Analysis between Indonesia and Malaysia. Aji, HM, Maizatulaidawati, MH dan B, Izra. s.1. : Cogent Business \& Management, 2020 Vol. 7.

7. Preferensi Masyarakat Indonesia dalam Melakukan Transaksi Konsumsi dengan e-Wallet dan Tunai. Islamiyah, RN, A, Ima dan R, Westi. 1, s.1. : Prosiding Ilmu Ekonomi, 2020, Vol. 6. 